\title{
Civil Society and State: A Historical Review
}

\author{
Venugopal B Menon*† and Chinnu Jolly Jerome* ${ }^{*}$
}

\section{Abstract}

The article attempts to trace the evolution of the concept of civil society. Drawing from the work of political philosophers from the classical period, the period of renaissance, scientific revolution, the period of Enlightenment in the 18th century, and ideologies from the Marxist and Gramscian discourses, the article demonstrates the shifts in the meaning and implications of the concept, its relations to public spaces, accountability, governance, normative ideals of state and the relationship between the state and its citizens. The article concludes its historical progression with the New Social Movements (NSMs), wherein the civil society became synonymous with strategic action to construct 'an alternative social and world order', a site for problem solving. Other contenders who put forth a renewed interest in the resurgence of civil society were the New Left, who assigned civil society a role to defend people's democratic will in the face of state power, and the neoliberals who considered civil society as a site for subversion from authoritarian regimes. The article finally concludes with a call for urgent attention towards reclaiming the authority of the civil society in education scenario.

\footnotetext{
${ }^{*}$ Christ University, Bengaluru, India;

† venugopal.menon@christuniversity.in;

‡ specialedition93@gmail.com
} 
Keywords: State, Civil Society, Classical Thinkers, Contemporary Society, Intellectual Freedom

\section{Introduction}

The term civil society in its modern usage is traced to the period of Enlightenment in the $18^{\text {th }}$ century. However, it has much older history in the realm of political thought. In the classical period, the concept was used as a synonym to good society, and seen as indistinguishable from the state. Generally, civil society has been referred to as a political association governing social conflict through the imposition of the rules that restrained citizens from harming one another (Edwards, 2004). For instance, Socrates admonished that conflicts within society should be resolved through public argument using 'dialectic', a form of rational dialogue to uncover truth. According to Socrates, public argument through 'dialectic' was imperative to 'civility' in the polis and 'good life' of the people (O'Brien, 1999).

For Plato, the ideal state was a just society in which people dedicate themselves to the common good, practice civic virtues of wisdom, courage, moderation and justice, and perform the occupational role to which they were best suited. It was the duty of the 'Philosopher King' to look after the people in the civility (ibid.). As far as Aristotle was concerned, polis was an 'association of associations' that enables citizens to share in the virtuous task of ruling and being ruled (Edwards, 2004). If we analyse the political discourse in the classical period, we can see the importance of a 'good society' in ensuring peace and order among the people. The philosophers in the classical period did not make any distinction between state and society. Rather they held that state represented the civil form of society and 'civility' represented the requirement of good citizenship (ibid.). Moreover, they held that human beings are inherently rational, therefore, they can collectively shape the nature of the society they belong to. In addition to that, the human beings have the capacity to voluntarily gather for the common cause and maintain peace in society. By holding this view, we can say that the classical political thinkers had endorsed the genesis of civil society in the original sense. 
However, the milieu in the medieval period shadowed the concept of the rationality of human beings as proposed by the classical political thinkers. It was a time when the absolutism of the church and feudalism got the momentum. Nevertheless, the developments in Europe since the fourteenth century further stimulated the revival of the concept of 'human rationalism'. This influenced the shaping of state-civil society relations to a great extent.

Renaissance stimulated the growth of humanism. Francesco Petrarch, Giovanni Pico della Mirandola, Guarino Veronese, Vittorino da Feltre, Lorenzo Valla, Leonardo Burni and Leon Battista Alberti were the champions of renaissance humanism. The renaissance humanists were instrumental in returning to the classical texts in Greek and Latin (Knutsen, 1997). Therefore, the original works of Plato, Aristotle and Cicero were subjected to serious reading. As a result, the concern for social values, individualism and intellectual freedom regained momentum. Humanists believed in the dignity and potential of human beings. Many of them were the supporters of Republican ideology that held that human beings could independently shape their political environment. As a result, the focus was shifted from theology to human autonomy. The central theme of art, literature and architecture became human beings rather than God. Then the 'honest doubt' began to challenge 'unreasoning faith'. Reliance upon faith and God weakened (ibid.). The distinction between this world (the city of man) and the next (the city of God) tended to disappear. Rather, the city of man and his happiness became important than everything else. Because, by then, the expansion of trade, growth of prosperity, luxury and widening social contacts generated interests in worldly pleasures. The humanists questioned all forms of absolutism and argued in favour of individual freedom. Later, it conducted to the germination of ideas such as individual rights, human security, secularism and democracy.

The scientific revolution in the 16th century intensified the cadence of reason and empiricism. The scientific revolution replaced faith by positivism and feudalism by capitalism (ibid.). This substantively changed the existing socio-political and religious institutions in Europe. The scientific revolution created a new and orderly vision of the world. Leading thinkers in natural philosophy 
were trying to understand the universe by deploying reason and empiricism. Their experiments brought out scientific knowledge about the universe. Advancements in the fields of astronomy and cartography proved the capacity of science to uncover truth. Naturally, science became essential to understand and explain the real world (ibid.).

Having been influenced by the scientific rigour, the political philosophers of the time held that social relations also could be ordered like that of the natural philosophy. Some of their attempts led to the emergence of the social contract theory that explains state-society relations in accordance with the human nature. They held that human nature could be understood by analysing objective realities and natural laws. Moreover, they also endorsed that the nature of human being determined the contours of state-society relations. Because of his experience with the English Civil War, Thomas Hobbes underlined the need of a powerful state to maintain civility in society. For Hobbes, human beings are motivated by self-interests (Graham, 1997). Moreover, the selfinterests of human beings are often contradictory in nature. Therefore, in state of nature, there was a condition of all against all. In such a situation, life was "solitary, poor, nasty, brutish and short" (ibid.). Upon realising the danger of the anarchy, human beings became conscious of the need of a mechanism to protect them. As far as Hobbes was concerned, he believed that rationality and selfinterests persuaded human beings to combine in agreement, to surrender sovereignty to a common power (Kaviraj, 2001). Hobbes called this common power, state, as a Leviathan.

Social contract theory of Thomas Hobbes set forth two types of relationship. One was vertical, between the Leviathan and the people; therefore, the latter surrendered them to the former. The second system was the realm of horizontal relationship among the people. In that system, people, under the surveillance of Leviathan, were compelled to limit their natural rights in a way that it did not harm others' rights. The first system denotes the state and the second represents civil- society in the present meaning. Hobbes' paradigm shows that the formation of the state conduced to the formation of civil society. Therefore, in his view, the state is imperative to sustain civility in society. Thus, Hobbes' account of 
'state of nature' and the 'sovereignty of the state' conduced to the germination of realism in later period that defined the nature and relationship between the state and civil society.

Contrary to Hobbes, John Locke had a different experience of the political condition in England. It was the period of Glorious Revolution marked by the struggle between the divine right of the Crown and the political rights of the parliament. This influenced Locke to forge a social contract theory of a limited state and a powerful society. In Locke's view, human beings led a peaceful life in state of nature.

The thinking is that individuals have interests and desires that drive them to cooperate with others, but that this cooperation is either impossible (Hobbes) or likely to be achieved only at sub-optimal levels (Locke) in the absence of some mechanism for esnsuring that agreements are adhered to; that is, without the coercive power of the state. (Brown \& Ainley, 2009, p. 74)

From that major concern, people gathered together to sign a contract and constituted a common public authority. Nevertheless, Locke held that the consolidation of political power can be turned into autocracy, if it was not brought under reliable restrictions (Kaviraj, 2001). Therefore, Locke set forth two treaties on government with reciprocal obligations. In the first treaty, people submit themselves to the common public authority. This authority has the power to enact and maintain laws. The second treaty contains the limitations of the authority i.e., the state has no power to threaten the basic rights of the human beings. As far as Locke was concerned, the basic rights of human beings denote the preservation of life, liberty and property. Moreover, he held that the state must operate within the bounds of civil and natural laws.

According to Locke, the 'civility' in social life was prior to the birth of the state, because, in his view, people led a peaceful life in the state of nature. Therefore, Locke advocated the primacy of society over the state. Lockean account of state of nature, basic rights, primacy of society and limits of the state were later conduced to the formation of liberal tradition that has a distinct notion about statecivil society relations. 
Both Hobbes and Locke had set forth a system, in which peaceful coexistence among human beings could be ensured through social contract. They considered civil society as a sphere that maintained civil life, the realm where civic virtues and rights were derived from natural laws. However, they did not hold that civil society was a separate realm from the state. Rather, they underlined the coexistence between the state and civil society. The systematic approaches of Hobbes and Locke (in their analysis of social relations) were largely influenced by the experiences in their period. Their attempts to explain human nature, natural laws, social contract and the formation of the government had challenged the divine right theory. Apart from divine right, Hobbes and Locke claimed that human intellect can design its political order. This idea had a great impact on the thinkers in the Enlightenment period.

The Thirty Years War and the subsequent Treaty of Westphalia in 1648 heralded the birth of the modem state system. The Treaty endorsed the state as the territorially based political units having sovereignty. As a result, the monarchs were able to extend control domestically by emasculating the feudal lords and were successful in curbing their dependence on the latter for the provision of armed troops (Brown, 2001). Therefore, monarchs could form national army, deploy professional bureaucracy and fiscal departments. In this way, monarchs maintained direct control and supreme authority over their subjects. In order to meet the administrative expenditure, monarchs used to control the economy. This gave birth to absolutism (Knutsen, 1997). Until the mid-eighteenth century absolutism was the hallmark of Europe (ibid.).

The absolutist nature of the state was challenged in the Enlightenment period (Chandhoke, 1995). As a natural consequence of renaissance, humanism and scientific revolution, the Enlightenment thinkers raised fundamental questions such as "what legitimacy does hereditary confer", "why are government instituted", "why should some human beings have more basic rights than others" and so forth. These questions led them to make certain assumptions about the nature of the human mind, the then political and moral authority, reason behind absolutism, and a better way to get out of it. The Enlightenment thinkers believed in the inherent goodness of the human mind. They opposed the 
alliance between the state and the Church as the enemy of human progress and well-being because the coercive apparatus of the state curbed individual liberty and the Church legitimated monarchs by posting the theory of divine origin. Therefore, both were seen as working against the will of the people.

The Enlightenment thinkers argued that human beings are rationally capable of determining their destiny. Hence, there was no need for invoking an absolute authority to control them. Both Jean Jacques Rousseau and Immanuel Kant argued that people are peace lovers and the wars are the creation of absolute regimes (Burchill, 2001). Having compared the despotic France and democratic America, Alexis de Tocqueville put weightage to the system of a limited state and voluntary associations. As far as he was concerned, this system was effective to guard against the domination of a single interest and check the tyranny of the majority (Alagappa, 2004).

With his inherent opposition to mercantilism, Adam Smith argued that wealthy state might become despotic, that would lead to wars and territorial conquests. Therefore, he advocated the separation of economy from the state (Burchill, 2001). Many thinkers in the Enlightenment movement held that mercantilism augmented the power of the despotic state, and it did not aim at the welfare of the people. In their view, the only way to avoid that menace was to make economic activity as an autonomous realm. Moreover, the power of the state should be limited so that the economic activity was free from the intervention of the former (ibid.).

Apart from their ancestors, the leading thinkers of the Enlightenment considered civil society as a separate realm that stood for the protection of individual rights and private property. Conceiving this idea, Hegel held that civil society had emerged at the particular epoch of capitalism, therefore, it serves its interests: individual rights and private property (Dhanagare, 2001). Hence, he used the German term Buergerliche Gesellschaft (bourgeois society) to denote civil society (Baynes, 2002). For Hegel, civil society manifests contradictory behavior. As the public sphere of ideas, civil society stands for certain collective interests and moral order. At the same time, being the realm of capitalist interest, there is a possibility of conflicts and inequalities within civil society. 
Therefore, the constant surveillance of the state is imperative to sustain the 'civility' in society. Hegel considered the state as the highest form of ethical life. Therefore, the state has the capacity and authority to correct the fault points in civil society (ibid.).

This was the theme taken further by Karl Marx. For Marx, civil society was the 'base' where productive forces and social relations engaged. Agreeing with the link between capitalism and civil society, Marx held that the latter represents the interests of the bourgeoisie (Edwards, 2004). Therefore, the state (superstructure) also represents the interests of the dominant class; under capitalism, it maintains the domination of the bourgeoisie. Hence, Marx rejected the positive role of state put forth by Hegel. Marx argued that the state could not be a neutral problem solver. Rather, he depicted the state as the defender of the interests of the bourgeoisie. He considered the state and civil society are the executive arms of the bourgeoisie, therefore, both their roles and purposes should be reconsidered (Brown, 2001).

With Antonio Gramsci however, we witnessed a revival of the term, civil society in contemporary times (Edwards, 2004). Gramsci did not consider civil society as coterminous with the socioeconomic base of the state. Rather, Gramsci located civil society in the political superstructure. He underlined the crucial role of civil society as the contributor of the cultural and ideological capital for the survival of the hegemony of capitalism (Ehrenberg, 1999). Gramsci used the term 'hegemony' to denote the predominance of one social class over others. This represents not only political and economic control, but also the ability of the dominant class to project its own way of seeing the world as good so that those who are subordinated by it accept it as natural. It is a way to keep the subordinate class in undying subordination with their consent, cooperation and collaboration. According to Gramsci, the hegemony of the capitalism in the West was maintained by its deep-rooted influence in every spheres of society.

Analysing the realities in the capitalist West and the Russian Revolution, Gramsci endorsed the importance of shaping the cultural and ideological contours of civil society. He depicted civil society as the site for challenging the existing values and inculcating new ones in the counter-hegemonic struggle against 
capitalism (Edwards, 2004). Gramsci's conception of civil society includes all social institutions that are non-production related, nongovernmental, and non-familial ranging from recreational groups to trade unions and political parties (Alagappa, 2004).

With the emergence of New Social Movements (NSMs), civil society became a key terrain of strategic action to construct 'an alternative social and world order.' Rather than posing as a problem, as in the earlier Marxist account, Gramsci viewed civil society as the site for problem solving. Agreeing with this view, the New Left assigned civil society a key role in defending people against the state and market and in formulating democratic will to influence the state (ibid.). At the same time, the neoliberals consider civil society as a site for struggle to subvert authoritarian regimes (ibid.). Thus, the term civil society appropriated an important place in the political discourses of the New Left and neoliberals.

While it is laid out how the civil society evolved, as a concept throughout the ages, with the influence of several philosophical, social and political movements, its role in education needs to be deliberated further. Civil Society does play crucial role in the arena of education. After the World Education Conference held in Dakar in 2000, the international community is formally committed to the right to education for all globally. Today education is not the sole responsibility of the state; it can be achieved through the help of civil society. A range of civil society networks have organised themselves to make sure that these international commitments translate into concrete practice on the ground. Ever since the era of globalization, state seems to be retracting from the social sector while non-governmental actors intervene as important facilitators in the nation building process. Non-governmental Organizations (NGOs) have proved to be quite effective in reaching out to the vulnerable section of the society for supporting their educational purpose without the impediments of the bureaucratic inertia. Governments too have moved forward to seek support from NGOs for preparing the curriculum, teachers training and effective classroom methods. Similarly, civil society itself can become the contributor for education instead of the governments' grant or resource allocation. Indeed civil society interacts with the 
community for the better living-condition of the people and education is one of the basic components in this interaction.

\section{References}

Brown, C. (2001). Understanding international relations. New York: Palgrave.

Brown, C., \& Ainley, K. (2009). Understanding international relations. New York: Palgrave Macmillan.

Chandhoke, N. (1995). State and civil society: Explorations in political theory. New Delhi: Sage.

Edwards, M. (2004). Civil society. Cambridge: Polity Press.

Ehrenberg, J. (1999). Civil society: The critical history of an idea. New York: New York University Press.

Graham, G. (1997). Ethics and international relations. Oxford: Blackwell.

Knutsen, T. L. (1997). A history of international relations theory. Manchester and New York: Manchester University Press. 